Editorial

\title{
Rising to a Challenge? Ten Years of Parliamentary Accountability of the European Semester
}

\author{
Tomasz P. Woźniakowski ${ }^{1, *}$, Aleksandra Maatsch ${ }^{2}$ and Eric Miklin ${ }^{3}$ \\ ${ }^{1}$ Hertie School, Germany; E-Mail: wozniakowski@hertie-school.org \\ ${ }^{2}$ Willy Brandt Centre for German and European Studies, University of Wroclaw, Poland; \\ E-Mail: aleksandra.maatsch@uwr.edu.pl \\ ${ }^{3}$ Department of Political Science, University of Salzburg, Austria; E-Mail: eric.miklin@sbg.ac.at \\ * Corresponding author
}

Submitted: 13 July 2021 | Published: 13 August 2021

\begin{abstract}
As a result of the euro crisis, EU economic governance has been reformed and EU institutions have gained new competences regarding national budgets, with the European Semester (the annual cycle of economic surveillance of the member states) being the most prominent example. With the Commission and the Council being the main actors, and the European Parliament playing only a minor role, a debate about the democratic legitimacy of the Semester and the role of national parliaments (NPs) in this regard has unfolded. This thematic issue, therefore, addresses the question of how parliamentary accountability of the European Semester has evolved: Have NPs met the challenge by adapting to the new situation in a way that allows them to hold the executive accountable? While the contributions to this thematic issue show significant variation across NPs, overall they reveal a rather pessimistic picture: Despite several institutional innovations concerning the reforms of internal rules and procedures, the rise of independent fiscal institutions, inter-parliamentary cooperation, and hearings with the European Commissioners, NPs have remained rather weak actors in EU economic governance also ten years after the Semester's introduction. Whether recent changes linked to the establishment of the Recovery and Resilience Facility introduced in response to the Covid-19 crisis will change the picture significantly remains to be examined.
\end{abstract}

\section{Keywords}

accountability; EU Economic Governance; European Parliament; European Semester; European Union; national parliaments

Issue

This editorial is part of the issue "Rising to a Challenge? Ten Years of Parliamentary Accountability of the European Semester" edited by Eric Miklin (University of Salzburg, Austria), Aleksandra Maatsch (University of Wroclaw, Poland) and Tomasz P. Woźniakowski (Hertie School, Germany).

(C) 2021 by the authors; licensee Cogitatio (Lisbon, Portugal). This editorial is licensed under a Creative Commons Attribution 4.0 International License (CC BY).

\section{Introduction}

The eurozone crisis, starting in 2010, demonstrated that the monetary union's initial institutional design which sought to maintain a balance between monetary integration and policy diversity at the national level was not sustainable (Crum, 2013). When discussing how to fix the problem, however, neither deeper integration towards a genuine fiscal union, nor the restora- tion of sovereignty through a return to national currencies found sufficient political support amongst member states. Instead, the EU opted for a third way: executive fiscal federalism. European economic governance was reformed predominantly by means of various intergovernmental measures-probably the most important being the European Semester (ES). As an annual cycle of economic surveillance of the member states, the ES combines the Stability and Growth Pact with a new 
instrument to address macro-economic imbalances and social and employment coordination. It combines several coordination mechanisms which aim to motivate or force member state reform, including semi-binding and non-binding rules. With the member states in the Councils and the European Commission being the main actors in the process, this system aims to provide the EU with the ability to pursue economic integration, steer national economies, and avoid imbalances while, at the same time, ensuring that member states' governments remain in the driver's seat.

This may come at a price, though. While budgetary powers in the ES formally remained with national parliaments (NPs), the new instruments acquired by the Commission and the Council(s) to influence national budgets means that de facto NPs' policy-choices today are increasingly constrained and that the only way to make their voices heard in the ES is indirectly, via their governments. In addition, this loss of parliamentary involvement is not compensated for at the European level either, as the European Parliament (EP) plays only a minor role in the ES. According to Rodrik (2011), the EU faces a trilemma between economic integration, national sovereignty, and democracy as only two out of the three can be preserved at the same time. With member states willing to give away neither power nor the euro, did they sacrifice democracy instead?

Just before the eurozone crisis, the Treaty of Lisbon, heralded as the 'treaty of parliaments' (Rittberger, 2014), significantly strengthened the competences of the EP and NPs in European policy-making (de Witte, 2009). In doing so, it marked a new peak of a steady process of the EU's parliamentarisation that started in the early 1990s and concerned both the EP (Rittberger, 2005) and NPs (Hefftler et al., 2015; Raunio, 2000). Ten years after the introduction of the ES, this thematic issue addresses the question of how and to what extent this new system of EU economic governance has affected the process of parliamentarisation: Has it come to a (temporary) end? Or have parliaments been able to 'fight back' (Raunio, 2000) once again? How have parliaments responded to the challenge posed through the ES-both institutionally and in their actual practices? And what have the results been for the EU's parliamentary accountability?

Building on Auel (2007, p. 500), we define parliamentary accountability as Members of Parliament' (MPs') oversight of the domestic executive or other institutions such as the European Commission. The core of the accountability process, which can be voluntary as in the case of the European Commission, is to provide pertinent answers regarding both past and planned policies and behaviour. Thus, accountability as a chain of exchanges can be divided into two basic forms, depending on the type of questions asked (Auel, 2007):

1. Justification, or the 'lighter' form of accountability, including questions demanding information and explanation;
2. Contestation, or the 'heavier' form of accountability, including statements of disagreement, requests for change, and sanctions.

Research on this topic so far provides a divided view. Some argue that in the "dense web of European surveillance, the capacity of NPs to scrutinize the choices of their governments has become severely strained" (Crum, 2018, p. 15). Others again argue that parliaments actually have used the crisis to "improve their position in budgetary process compared to the situation before the euro crisis" (Pernice, 2017, p. 128; see also Fasone, 2015; Jancic, 2016). The articles of this issue contribute to the debate by looking not only at (differences in) changes regarding formal institutional set-ups on the national and the European level as a reaction to the ES but also in the actual practices of parliaments and these practices' substantive effect on the democratic accountability of national and European executives in EU economic governance.

\section{Overview of Contributions}

Overall, the articles reveal a picture that is wellknown from research on NPs in the EU more generally (Hefftler et al., 2015). As in the past, reactions have not been uniform but varied across parliaments. Looking at formal changes, Winzen (2021) shows that indeed many, but not all, parliaments have reformed their procedures and institutional powers after the ES was introduced-providing support to the strengthening argument. He identifies eurozone membership and formally strong institutions as a necessary condition for reform. Looking at the actual amount of ES-related activities, Skazlic (2021) also finds significant variation across NPs. Again, formal power is one of the two strongest predictors - the other being a member states' debt level. In general, however, Skazlic's findings suggest that attention to, and activities in the ES overall are limited. This picture is also supported through Schweiger's (2021) case study on the Polish parliament. In Poland, the ES has remained an elite-driven process, strongly geared towards EU-level executive bargaining between the government and the Commission at the expense of domestic parliamentary scrutiny.

In addition to strengthening their own powers, NPs have established alternative paths to increase their standing in the process. First, eurozone parliaments have introduced or reformed their independent fiscal institutions to counter information asymmetries vis-à-vis their governments. Looking at the actual effect of these bodies in three member states, however, the article by Fasone (2021) shows that so far they have had little effect on parliamentary accountability in the eurozone. The same can be said for the Inter-Parliamentary Conference on Stability, Economic Coordination and Governance. Meeting twice a year, this conference provides a forum for NPs and the EP to exchange their views 
on economic governance and budget policy amongst each other and with the European Commission. Looking at NPs' own perceptions, Borońska-Hryniewiecka (2021) again suggests that participation neither increases parliamentary activities at home nor does it significantly improve domestic scrutiny. A third way for NPs to engage in the ES is through direct discussion with the European Commission. The Commission intended that these meetings would increase the often poor implementation rates of recommendations emanating from the ES. Analysing the debates between the Commission and MPs in the Polish parliament, the article by Woźniakowski (2021) shows that these discussions failed to meet their original purpose as they had no significant effect on implementation rates. However, these discussions have contributed to building expertise by NPs and enhancing the accountability of the Commission.

The last two articles discuss the potential effect of the Covid-19 crisis on parliamentary accountability in EU economic governance. In response to the economic downturn caused by the pandemic, the EU introduced several new policy instruments, most notably the Recovery and Resilience Facility (RRF), an EU fund of $€ 672.5$ billion in loans and grants available to member states to support reforms and investments undertaken to recover from the crisis. Payments from the RRF are linked to the country-specific recommendations adopted in the ES. As the RRF's ratification required the EP's consent, Closa Montero et al.'s (2021) study investigated whether the EP had-once again-tried to use this 'window of opportunity' to claim a more important role in the ES. The authors show that the EP did indeed intend to link its agreement to the RRF with a stronger role in the RRF. Success was limited, though: While the EP played an important role during negotiations and obtained important policy concessions, institutional concessions were limited to having 'a seat at the table.' Finally, Bekker (2021) discusses the potential impact of the RRF on NPs' future standing in the ES. She concludes that, while NPs are not officially acknowledged, the RRF's provisions leave enough space for NPs to claim their role in developing national plans for accessing financial support as well as in amending and approving reforms. Additionally, the RRF might motivate NPs to engage in the ES more actively, given the latter's more prominent role due to its links with the RRF.

In sum, the findings of this issue support the critical view on parliamentary accountability of the ES rather than the positive one. Despite numerous institutional innovations, such as the rise of independent fiscal institutions, inter-parliamentary cooperation, reformed internal rules and procedures, and hearings with the European Commissioners, NPs remain rather weak actors in EU economic governance-and this legitimacy vacuum is not compensated for by the EP. Most NPs are not systematically involved in accountability-rendering exercises, and it remains to be seen whether this will change significantly as a result of the Covid-related insti- tutional changes, such as the link between the RRF and the ES. Weak parliamentary accountability could be understandable in times of crises (such as during the eurozone- or the Covid-crisis), which commonly are referred to as 'the hour of the executive.' It is less clear why potentially very intrusive mechanisms of the ES are not politically salient enough to spark parliamentary accountability, preferably by contestation, i.e., the 'heavier' form of accountability, and not merely justification. Explaining this phenomenon-why the NPs are not active in the ES in 'normal' times-may be an avenue for future research.

\section{Acknowledgments}

The thematic issue has been supported by the German Academic Exchange Service (DAAD) within the framework of "Networking Projects for the Centres for German and European Studies 2019," principal investigator Aleksandra Maatsch, as well as the NCN-OPUS "PANDEMO" 0201/0070/21, UMO-2020/37/BS5/00328, principal investigator Aleksandra Maatsch. This research was supported by funding from the European Research Council under the European Union's Horizon 2020 research and innovation programme (grant agreement no. 716923).

\section{Conflict of Interests}

The authors declare no conflict of interests.

\section{References}

Auel, K. (2007). Democratic accountability and national parliaments: Redefining the impact of parliamentary scrutiny in EU affairs. European Law Journal, 13(4), 487-504.

Bekker, S. (2021). The EU's recovery and resilience facility: A next phase in EU socioeconomic governance? Politics and Governance, 9(3), 175-185.

Borońska-Hryniewiecka, K. (2021). Accountability revisited: Parliamentary perspectives on the interparliamentary conference on stability, economic coordination, and governance. Politics and Governance, 9(3), 145-154.

Closa Montero, C., González De León, F., \& Hernández González, G. (2021). Pragmatism and the limits to the European Parliament's strategies for self-empowerment, Politics and Governance, 9(3), 163-174.

Crum, B. (2013). Saving the euro at the cost of democracy? Journal of Common Market Studies, 51(4), 614-630.

Crum, B. (2018). Parliamentary accountability in multilevel governance: What role for parliaments in postcrisis EU economic governance? Journal of European Public Policy, 25(2), 268-286. https://doi.org/ 10.1080/13501763.2017.1363270 
de Witte, B. (2009). The Lisbon Treaty and national constitutions-More or less Europeanisation? In C. Closa (Ed.), The Lisbon Treaty and national constitutions. Europeanisation and democratic implications (ARENA Report No. 3/09, pp. 25-48). ARENA.

Fasone, C. (2015). Taking budgetary powers away from national parliaments? On parliamentary prerogatives in the eurozone crisis (EUI LAW Working Paper No. 2015/37). European University Institute. https:// cadmus.eui.eu/handle/1814/36658

Fasone, C. (2021). Do independent fiscal institutions enhance parliamentary accountability in the eurozone? Politics and Governance, 9(3), 135-144.

Hefftler, C., Neuhold, C., Rozenberg, O., \& Smith, J. (Eds.). (2015). The Palgrave handbook of national parliaments and the European Union. Palgrave Macmillan.

Jancic, D. (2016). National parliaments and the EU fiscal integration. European Law Journal, 22(2), 225-249.

Pernice, I. (2017). Financial crisis, national parliaments, and the reform of the Economic and Monetary Union. In D. Jancic (Ed.), National parliaments after the Lisbon Treaty and the euro crisis: Resilience or resignation? (pp. 115-139). Oxford University Press.

Raunio, T. (2000). Losing independence or finally gaining recognition? Contacts between MEPs and national parties. Party Politics, 6(2), 211-223.

Rittberger, B. (2005). Building Europe's parliament: Democratic representation beyond the nation state. Oxford University Press.

Rittberger, B. (2014). Integration without representation? The European Parliament and the reform of economic governance in the EU. Journal of Common Market Studies, 52(6), 1174-1183.

Rodrik, D. (2011). The globalization paradox: Democracy and the future of the world economy. W. W. Norton.

Schweiger, C. (2021). Parliamentary scrutiny of the European Semester: The case of Poland. Politics and Governance, 9(3), 124-134.

Skazlic, I. (2021). Routine or rare activity? A quantitative assessment of parliamentary scrutiny in the European Semester. Politics and Governance, 9(3), 112-123.

Winzen, T. (2021). The European Semester and parliamentary oversight institutions inside and outside of the euro area. Politics and Governance, 9(3), 100-111.

Woźniakowski, T. P. (2021). Accountability in EU economic governance: European commissioners in Polish parliament. Politics and Governance, 9(3), 155-162.

\section{About the Authors}

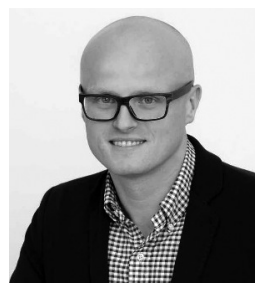

Tomasz P. Woźniakowski is a Doctor of Political and Social Sciences of the European University Institute in Florence (2018), a Post-Doctoral Researcher for Leviathan, an ERC-funded project at the Hertie School, and a Lecturer at Stanford University (Berlin). His research focuses on the US and EU fiscal unions in a comparative historical perspective and parliamentary accountability in EU economic governance.

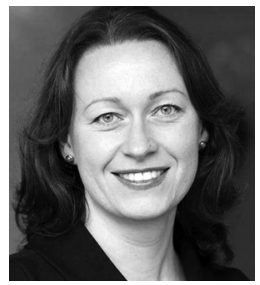

Aleksandra Maatsch holds the Chair in Social Sciences and Economics at the Willy Brandt Centre for German and European Studies, University of Wrocław. She acquired her PhD in political science from the University of Bremen in Germany (2011). Aleksandra Maatsch then worked at the Institute of Public Affairs (IPP-CSIC) in Madrid, at the University of Cambridge, the Max Planck Institute in Cologne, and the University of Cologne (interim Chair of European and Multilevel Politics). She specializes in comparative European politics and legislative studies.

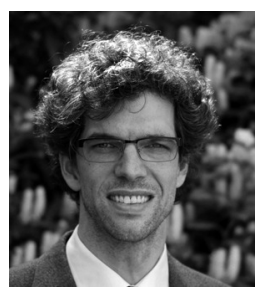

Eric Miklin is Associate Professor of Austrian Politics in Comparative European Perspective in the Department of Political Science at the University of Salzburg, Austria. He received his Doctorate from the University of Vienna, Austria, in 2008. Before joining the University of Salzburg, Miklin held positions at the Free University Amsterdam and the Institute of Advanced Studies Vienna. He specialises in comparative European politics and European integration with a special focus on national parliaments and parties. 